\title{
Şehriban Koca
}

Mersin University

sehriban.koca@mersin.edu.tr

Mersin-Turkey

http://dx.doi.org/10.12739/NWSA.2013.8.2.D0133

\section{ORTAÖĞRETIM MÜZİK DERSİ ÖĞRETİM PROGRAMININ MÜZİK ÖĞRETMENLERINNİN GÖRÜŞLERI DOĞRULTUSUNDA DEĞERLENDİRİLMESİ}

\section{ÖZET}

Bu araştırmada ortaöğretim müzik dersi öğretim programının müzik öğretmenlerinin bakış açısıyla değerlendirilmesi amaçlanmıştır. Araştırmanın çalışma grubunu 2011 yılında Mersin ilinde görev yapan ve araştırmaya gönüllü olarak katılan 50 müzik öğretmeni oluşturmaktadır. Araştırma betimsel bir çalışma olup, nicel ve nitel araştırma teknikleri kullanılarak desenlenmiştir. Araştırmada veriler araşırmacı tarafından geliştirilen "Ortaöğretim Müzik Dersi Öğretim Programı Değerlendirme Anketi" ve üçer açık uçlu soru kullanılarak toplanmıştır. Araştırmadan elde edilen nicel verilerin analizinde, frekans ve yüzdeler ile aritmetik ortalama ve standart sapma dağılımları kullanılmış, açık uçlu sorulara verilen yanıtlardan elde edilen nitel veriler ise içerik analizi kullanılarak değerlendirilmiştir. Araştırma sonucu uygulamada bazı sorunlar yaşandığı saptanmıştır.

Anahtar Kelimeler: Ortaöğretim, Müzik Dersi Öğretim Programı, Müzik Öğretmenleri, Müzik Eğitimi, Program Değerlendirme

\section{THE EVALUATION OF SECONDARY SCHOOL MUSIC LESSONS CURRICULUM IN TERMS OF MUSIC TEACHERS' PERSPECTIVES}

\section{ABSTRACT}

This study aims to make an evaluation of secondary school music lessons curriculum in terms of music teachers' perspectives. Study group of the study consisted of a total of 50 music teachers working in Mersin province. "Secondary school music lessons music education curriculum evaluation questionnaire" and there open-ended questions which was developed by the researcher was used as main data collection tool. Descriptive statistics and content analysis techniques were used in analyzing data. The results of the study showed that some problems have been seen the implementation stage.

Keywords: Secondary School, Music Lessons Curriculum, Music Teachers, Music Education, Curriculum Evaluation 


\section{GİİŞ (INTRODUCTION)}

"Müzik eğitimi, öğrencide çeşitli müziksel bilgi, beceri, tutum ve değerler edindirmeye yönelik yapılan bir süreçtir. Bu süreç içinde, öğrencinin yaşantısında var olan olgulardan yola çıkılarak ve düzenli plan, program ve yöntemlerle desteklenerek belirli hedeflere ulaşılır" (Milli Eğitim Bakanlığı [MEB], 2009:6).

Ülkemizde düzenli müzik eğitimi ilköğretim döneminde başlamaktadır. Ortaöğretim kurumlarında "Müzik" dersi seçmeli ders olarak haftada bir saat olarak yürütülmektedir."Ortaöğretim müzik dersi öğretim programının temel yaklaşımında, 2006 yılından itibaren uygulanmakta olan ilköğretim müzik programının devamı olarak, "yaparak öğrenme" ya da "öğrencinin aktif katılımının sağlanması" yoluyla yapılan yapılandırmacı yaklaşıma uygun olan bir eğitim-öğretim anlayışı benimsenmektedir. Bu yaklaşımla öğrenci merkezli, dolayısıyla etkinlik merkezli müzik eğitimi ile bilgi ve beceriyi dengeleyen, öğrencinin kendi yaşantılarını ve bireysel farklılıklarını dikkate alarak çevreyle etkileşimine olanak sağlayan yeni bir anlayış yaşama geçirilmeye çalışılmaktadır. Ortaöğretim müzik dersi öğretim programı, her öğrencinin müziği bir ders olarak değil, bir yaşam biçimi hâline dönüştürmesi hedeflenerek hazırlanmıştır. Ayrıca öğrencilere müziği sevdirmek, yaparak yaşayarak öğrenme yoluyla müzikten haz almalarını sağlamak ve estetik bir bakış açısı oluşturmak amacıyla öğrenciyi merkez alarak hazırlanmıs bir programdır" (Milli Eğitim Bakanlığı [MEB], 2009:6).

Öğretim programlarının öğrencilerin bilgiye ulaşma yollarını öğrenmelerine, sorun çözme ve karar verme becerilerini geliştirmelerine olanak sağlayacak şekilde yeniden düzenlenmesine ihtiyaç olduğu sıklıkla dile getirilmektedir (Milli Eğitim Bakanlığı [MEB], 2009:7). "Öğretmenlerin teorik olarak geliştirilen programları temel uygulayıcısı olmalarından dolayı onların sınıf içi programın uygulanmasi boyutuna ilişkin düşünceleri ve deneyimleri önemli olmaktadır" (Korkmaz, 2006:422.

"Bir eğitim program öğrencilerden çok öğretmenler için önem taşır. Eğer yeni bir eğitim program öğretmenleri değiştiremez ise; onları harekete geçiremez, zihinlerini karıştıramaz ya da bilgilendiremezse onların okuttukları ögrenciler üzerinde hiçbir etkisi olmaz. Bir program öncelikle öğretmenler için hazırlanmıs olmalıdır. Eğer ögrenciler üzerinde bir etkisinden bahsediliyorsa; bu ancak sözkonusu programın öğretmenler üzerindeki tesirimeziyetiyle gerçekleşmiştir demektir" (Bruner, 1977: xv, Akt. Dinç ve Doğan, 2010).

Eğitim programının amaçlarına ulaşması ve müziksel ve sanatsal aktivitelerin bireylerde yaşam tarzı olabilmesi için gerekli en önemli etkenlerden biri öğretim kurumlarındaki müzik öğretmenleridir (Taner ve Bilir, 2001:56; Ak.Özden, 2010:297). Program değişiklikleri ancak öğretmenler bu değişiklikleri anladıkları, kabullendikleri ve kullandıkları zaman başarıya ulaşabilir (Kalin ve Zuljan, 2007; Akt.Keleş, Haser ve Koç, 2012:716).

Bu görüşlerden hareketle çalışmada 2010-2011 eğitim öğretim yılından itibaren uygulanmakta ve yapılandırmacı yaklaşıma dayalı olan ortaöğretim müzik dersi öğretim programının Mersin ilinde görev yapmakta olan müzik öğretmenlerinin bakış açısıyla değerlendirilmesi amaçlanmıştır.

\section{2. ÇALIŞMANIN ÖNEMI (RESEARCH SIGNIFICANCE)}

2009 yılında yapılan program değişimi, uygulamada yaşanan eksikliklerin belirlenerek araştırmaların yapılması gerekliliğini doğurmuştur. Bu bă̆lamda yapılan alan yazın taramasında ortaöğretim 
müzik dersi öğretim programının değerlendirilmesine ilişkin herhangi bir çalışmaya rastlanmamıştır. "Öğretmenlerin program değişikliği hakkındaki görüşlerinin bilinmesi, onların programın uygulanışı sırasında yeni rollerine alışmaları sürecindeki ihtiyaçlarının belirlenmesi açısından önemlidir" (Keleş, Haser ve Koç, 2012:717). Çalışma bu açılardan önem arz etmektedir.

\section{YÖNTEM (METHOD)}

Bu araştırma 2010 yılında uygulamaya başlanılan ortaöğretim müzik dersi öğretim programı ile ilgili müzik öğretmenlerinin görüşlerinin belirlenmesinin amaçlandığı tarama modelinde betimsel bir çalışma olup, nicel ve nitel araştırma teknikleri kullanılarak desenlenmiştir.

\section{1. Çalışma Grubu (Study Group)}

Araştırmanın çalışma grubunu 2011 yılında Mersin ilinde görev yapan ve araştırmaya gönüllü olarak katılan 50 müzik öğretmeni oluşturmaktadır.

\subsection{Veri Toplama Aracı ( Research Instrument)}

Araştırmada veriler yapılan literatür araştırması sonucu araştırmacı tarafından geliştirilen "Ortaöğretim Müzik Dersi Öğretim Programı Değerlendirme Anketi" kullanılarak toplanmıştır. Anket üç bölümden oluşmaktadır. Birinci bölümde öğretmenlerin kişisel bilgilerini (cinsiyet, mezun olunan okul, öğrenim durumu, hizmet yılı, görev yapılan okul türü) toplamaya yönelik sorular yer almaktadır. İkinci bölümde öğretim programının içeriği doğrultusunda hazırlanan anket yer almaktadır. Uzman görüşleri doğrultusunda Likert tipi ölçek modeline uygun olarak düzenlenen ankette her bir ifade için beş kategori belirlenmiştir. Öğrencilerin, anketteki ifadelere katılma derecelerini, "hiç katılmıyorum", " katılmıyorum", "kararsızım", "katılıyorum" ve "tamamen katılıyorum" kategorilerinden birini seçerek belirtmeleri düşünülmüştür. Üçüncü bölümde ise öğretmenlere programın olumlu ve olumsuz buldukları yönleri ile önerilerini yazabilecekleri üçer açık uçlu soruya yer verilmiştir.

\subsection{Verilerin Analizi (Data Analysis)}

Araştırmadan elde edilen nicel verilerin analizinde, frekans ve yüzdeler ile aritmetik ortalama ve standart sapma dağılımları kullanılmış, açık uçlu sorulara verilen yanıtlardan elde edilen nitel veriler ise içerik analizi kullanılarak değerlendirilmiştir. Araştırmanın verilerini yorumlamak için aralık sayısı seçenek sayısına bölünerek sınırlar elde edilmiştir. Anketin seçenekleri ve puan aralıkları Tablo $1^{\prime}$ de verilmiştir.

Tablo 1. Ankete ilişkin seçenek ve puan aralıkları (Table1. Options and score ranges of questionnaire)

\begin{tabular}{|l|l|}
\hline Puan Aralığı & Seçenekler \\
\hline $1.00-1.80$ & Hiç Katılmıyorum \\
\hline $1.81-2.60$ & Katılmıyorum \\
\hline $2.61-3.40$ & Kararsızım \\
\hline $3.41-4.20$ & Katılıyorum \\
\hline $4.21-5.00$ & Tamamen Katılıyorum \\
\hline
\end{tabular}

\section{BULGULAR VE YORUM (FINDINGS AND COMMENTS)}

Araştırmaya katılan müzik öğretmenlerinin demografik özellikleri Tablo 2'de yer almaktadır. 
Tablo 2. Müzik öğretmenlerinin demografik özellikleri

(Table 2. Demographic information about music teachers)

\begin{tabular}{|c|c|c|c|}
\hline & & $\mathrm{N}$ & $\%$ \\
\hline \multirow{3}{*}{ Cinsiyet } & Kadın & 27 & 54 \\
\hline & Erkek & 23 & 46 \\
\hline & Toplam & 50 & 100 \\
\hline \multirow{5}{*}{ Mezun olduğu okul } & Eğitim Fakültesi & 43 & 86 \\
\hline & Güzel Sanatlar Fakültesi & 2 & 4 \\
\hline & Konservatuar & 3 & 6 \\
\hline & Diğer & 2 & 4 \\
\hline & Toplam & 50 & 100 \\
\hline \multirow{4}{*}{ Öğrenim Durumu } & Lisans & 45 & 90 \\
\hline & Yüksek Lisans & 5 & 10 \\
\hline & Doktora & - & - \\
\hline & Toplam & 50 & 100 \\
\hline \multirow{6}{*}{ Mesleki Kıdem } & $0-5 y \geq 1$ & 3 & 6 \\
\hline & $6-10$ yı1 & 12 & 24 \\
\hline & $11-15$ yı1 & 22 & 44 \\
\hline & $16-20 \mathrm{y} 11$ & 7 & 14 \\
\hline & $21+$ & 6 & 12 \\
\hline & Toplam & 50 & 100 \\
\hline
\end{tabular}

Tablo 2'de görüldüğü gibi, çalışma grubunu oluşturan öğretmenlerin 54'ü kadın, \%46'sı ise erkektir. Öğretmenlerin mezun oldukları okullar incelendiğinde; 86 sının Eğitim Fakültesi, 6 sının konservatuar, o4'ünün ise Güzel Sanatlar Fakültesi ve diğer fakültelerden mezun oldukları görülmektedir. Çalışma grubunu oluşturan öğretmenlerin öğrenim durumları incelendiğinde ise; öğretmenlerin o90'ının Lisans mezunu, \%10'unun ise yüksek lisans mezunu olduğu görülmektedir. Çalışma grubunun mesleki kıdemlerine göre dağılımları incelendiğinde; öğretmenlerin o6'sını 0-5 yıl,24'ünü 6-10 yıl, 44'ünü 11-15 yıl 14'ünü 16-20 yıl arası, o12 sini ise 21 yıl ve üzeri görev yapan öğretmenlerin oluşturduğu görülmektedir. 
Tablo 3. Müzik öğretmenlerinin ortaöğretim müzik dersi öğretim programına ilişkin görüşleri

(Table 3. The views of music teachers on secondary school music lessons curriculum)

\begin{tabular}{|c|c|c|c|c|c|c|c|c|c|c|c|c|c|}
\hline & \multicolumn{2}{|c|}{ 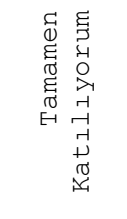 } & \multicolumn{2}{|c|}{ 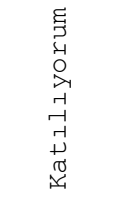 } & \multicolumn{2}{|c|}{ 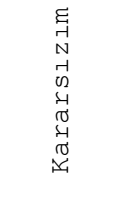 } & \multicolumn{2}{|c|}{ 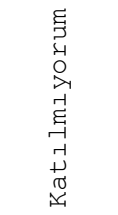 } & \multicolumn{2}{|c|}{ 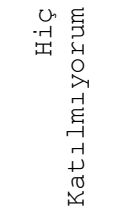 } & \multirow[t]{2}{*}{$X$} & \multirow[t]{2}{*}{ SS } & \multirow[t]{2}{*}{$\mathrm{N}$} \\
\hline & f & $\frac{\circ}{0}$ & $\mathrm{f}$ & $\%$ & $\mathrm{f}$ & $\frac{\circ}{0}$ & f & $\frac{\circ}{0}$ & f & $\frac{\circ}{0}$ & & & \\
\hline $\begin{array}{l}\text { 1.Programın } \\
\text { hazırlanmasında } \\
\text { öğretmen görüşleri } \\
\text { yeteri kadar } \\
\text { alınmıştır }\end{array}$ & - & - & 3 & 6 & 6 & 12 & 31 & 62 & 10 & 20 & 2.04 & .75 & 50 \\
\hline $\begin{array}{l}\text { 2. Programın } \\
\text { hazırlanma aşamasında } \\
\text { yeterli ön hazırlığın } \\
\text { yapıldığını } \\
\text { düşünmüyorum }\end{array}$ & 7 & 14 & 25 & 50 & 8 & 16 & 8 & 16 & 2 & 4 & 3.54 & 1.05 & 50 \\
\hline $\begin{array}{l}\text { 3.Programı uygulamadan } \\
\text { önce programla ilgili } \\
\text { ön bilgim vardı }\end{array}$ & 3 & 6 & 25 & 50 & 4 & 8 & 11 & 22 & 7 & 14 & 3.12 & 1.24 & 50 \\
\hline $\begin{array}{l}\text { 4. Program tanıtımının } \\
\text { zamanında yapıldığını } \\
\text { düşünmüyorum }\end{array}$ & 2 & 4 & 25 & 50 & 9 & 18 & 11 & 22 & 3 & 6 & 3.24 & 1.04 & 50 \\
\hline $\begin{array}{l}\text { 5. Programın } \\
\text { tanıtılması ve } \\
\text { uygulanmasıyla ilgili } \\
\text { yeterli hizmetiçi } \\
\text { eğitimi aldım } \\
\end{array}$ & 1 & 2 & 3 & 6 & 9 & 18 & 27 & 54 & 10 & 20 & 2.16 & .89 & 50 \\
\hline $\begin{array}{l}\text { 6. Program hakkında } \\
\text { istediğim bilgiye } \\
\text { anında ulaşabiliyorum }\end{array}$ & 6 & 12 & 28 & 56 & 6 & 12 & 7 & 14 & 3 & 6 & 3.54 & 1.07 & 50 \\
\hline $\begin{array}{l}\text { 7.Program içeriğinin } \\
\text { açıklayıcı ve } \\
\text { anlaşılır olduğunu } \\
\text { düşünüyorum }\end{array}$ & 5 & 10 & 21 & 42 & 16 & 32 & 7 & 14 & 1 & 2 & 3.44 & .93 & 50 \\
\hline $\begin{array}{l}\text { 8. Programın ders yılı } \\
\text { başında tekrar } \\
\text { tanıtılması } \\
\text { gerektiğini } \\
\text { düşünüyorum }\end{array}$ & 17 & 34 & 24 & 48 & 6 & 12 & 3 & 6 & - & - & 4.10 & .84 & 50 \\
\hline $\begin{array}{l}\text { 9. Geçmiş programdan } \\
\text { yeni programa geçişte } \\
\text { sorun yaşamadım }\end{array}$ & 3 & 6 & 3 & 6 & 8 & 16 & 33 & 66 & 3 & 6 & 2.40 & .93 & 50 \\
\hline $\begin{array}{l}\text { 10. Ders kitabı } \\
\text { kullanılmamasının } \\
\text { öğrencinin derse karşı } \\
\text { ilgisini } \\
\text { artırabileceğini } \\
\text { düşünüyorum }\end{array}$ & 3 & 6 & 16 & 32 & 13 & 26 & 9 & 18 & 9 & 18 & 2.90 & 1.22 & 50 \\
\hline $\begin{array}{l}\text { 11. Programı } \\
\text { uygulamada sorunlar } \\
\text { yaşıyorum }\end{array}$ & 9 & 18 & 32 & 64 & 5 & 10 & 4 & 8 & - & - & 3.92 & .78 & 50 \\
\hline $\begin{array}{l}\text { 12. Ünitelerde yer } \\
\text { alan bazı kazanımlar } \\
\text { öğrenci seviyesinin } \\
\text { üstündedir }\end{array}$ & 17 & 34 & 28 & 56 & 1 & 2 & 4 & 8 & - & - & 4.16 & .82 & 50 \\
\hline $\begin{array}{l}\text { 13. Programın } \\
\text { öğrencilerin } \\
\text { yaşantısını dikkate } \\
\text { alarak çevreyle } \\
\text { etkileşimine olanak } \\
\text { sağladığını } \\
\text { düşünüyorum }\end{array}$ & 1 & 2 & 21 & 42 & 16 & 32 & 7 & 14 & 5 & 10 & 3.12 & 1.02 & 50 \\
\hline
\end{tabular}




\begin{tabular}{|c|c|c|c|c|c|c|c|c|c|c|c|c|c|}
\hline $\begin{array}{l}\text { 14. Yeni ölçme } \\
\text { değerlendirme } \\
\text { tekniklerini } \\
\text { geleneksel } \\
\text { değerlendirme } \\
\text { anlayışına göre daha } \\
\text { iyi buluyorum }\end{array}$ & 2 & 4 & 25 & 50 & 15 & 30 & 6 & 12 & 2 & 4 & 3.38 & .90 & 50 \\
\hline $\begin{array}{l}\text { 15. Ölçme ve } \\
\text { değerlendirme } \\
\text { formlarını kullanırken } \\
\text { zorlanmıyorum }\end{array}$ & - & - & 7 & 14 & 13 & 26 & 27 & 54 & 3 & 6 & 2.48 & .81 & 50 \\
\hline $\begin{array}{l}\text { 16. Ölçme ve } \\
\text { değerlendirme } \\
\text { formlarının } \\
\text { kullanımının yorucu } \\
\text { olduğunu düşünüyorum }\end{array}$ & 8 & 16 & 32 & 64 & 7 & 14 & 3 & 6 & - & -- & 3.90 & .74 & 50 \\
\hline $\begin{array}{l}\text { 17. Program farklı } \\
\text { zeka gruplarına cevap } \\
\text { verebilecek } \\
\text { niteliktedir }\end{array}$ & - & - & 18 & 36 & 21 & 42 & 7 & 14 & 4 & 8 & 3.06 & .91 & 50 \\
\hline $\begin{array}{l}\text { 18. Ünitelerin } \\
\text { işlenişinde yapılması } \\
\text { gereken etkinliklerin } \\
\text { yeterli olduğunu } \\
\text { düşünmüyorum }\end{array}$ & 4 & 8 & 10 & 20 & 10 & 20 & 24 & 48 & 2 & 4 & 2.80 & 1.07 & 50 \\
\hline $\begin{array}{l}\text { 19. Konuların } \\
\text { işlenebilmesi için } \\
\text { ders saatini yeterli } \\
\text { bulmuyorum }\end{array}$ & 48 & 96 & 1 & 2 & - & - & - & - & 1 & 2 & 4.90 & .58 & 50 \\
\hline $\begin{array}{l}\text { 20. Programın öğrenci } \\
\text { merkezli olması işimi } \\
\text { kolaylaştırıyor }\end{array}$ & 7 & 14 & 21 & 42 & 16 & 32 & 4 & 8 & 2 & 4 & 3.54 & .97 & 50 \\
\hline $\begin{array}{l}\text { 21. Yeni programın } \\
\text { öğrencinin kendine } \\
\text { güvenini ve } \\
\text { yaratıcılığını } \\
\text { artırabileceğini } \\
\text { düşünüyorum }\end{array}$ & 8 & 16 & 22 & 44 & 11 & 22 & 6 & 12 & 3 & 6 & 3.52 & 1.09 & 50 \\
\hline $\begin{array}{l}\text { 22. Yeni programın } \\
\text { eğitim sistemine yeni } \\
\text { bir soluk getireceğini } \\
\text { düşünüyorum. }\end{array}$ & 3 & 6 & 19 & 38 & 21 & 42 & 3 & 6 & 4 & 8 & 3.28 & .97 & 50 \\
\hline
\end{tabular}

Tablo 3 incelendiğinde;

- "Programın hazırlanmasında öğretmen görüşleri yeteri kadar alınmıştır" önermesine öğretmenlerin o62'si katılmadıklarını, \%20'si hiç katılmadıklarını, \%6'sı ise katıldıklarını belirtmişlerdir. Genel ortalamanın 2.04 (katılmıyorum) düzeyinde olduğu görülmektedir. Bu sonuca göre program hazırlanırken öğretmenlerin düşüncelerinin yeteri kadar alınmadığı söylenebilir.

- "Programın hazırlanma aşamasında yeterli ön hazırlığın yapıldığını düşünmüyorum" önermesine öğretmenlerin o14'ü tamamen katıldıklarını, 50'si katıldıklarını, 16'sı katılmadıklarını, o4'ü ise hiç katılmadıklarını belirtmişlerdir. Genel ortalamanın ise 3.54 (katılıyorum) düzeyinde olduğu görülmektedir. Bu sonuca göre öğretmenlerin programın hazırlanma aşamasında yeterli ön hazırlığın yapıldığını düşünmedikleri söylenebilir.

- "Programı uygulamadan önce programla ilgili ön bilgim vardı" önermesine öğretmenlerin " $\sigma^{\prime} \operatorname{sinın~"tamamen~katılıyorum",~}$ 50'sinin "katılıyorum", 22'sinin "katılmıyorum", 14'ünün "hiç katılmıyorum" düzeyinde görüş bildirdikleri görülmektedir. Genel ortalama puanları incelendiğinde 3.12 (kararsızım) düzeyinde olduğu görülmektedir.

- "Program tanıtımının zamanında yapıldığını düşünmüyorum" önermesine öğretmenlerin 4'ünün "tamamen katılıyorum" 50'sinin 


\begin{tabular}{llll}
\hline \hline "katılıyorum", & o22'sinin "katılmıyorum", & o6'sının "hiç \\
katılmıyorum" & düzeyinde görüş bildirdikleri, genel ortalama \\
puanlarının & ise 3.24 & (kararsızım) duzeyinde
\end{tabular}
görülmektedir.

- Öğretmenlerin "Programın tanıtılması ve uygulanmasıyla ilgili yeterli hizmet içi eğitimi aldım" önermesine ilişkin görüşleri incelendiğinde; 54'ünün "katılmıyorum", 20'sinin "hiç katılmıyorum", 18'inin ise "kararsızım" düzeyinde görüş bildirdikleri görülmektedir. Genel ortalama puanlarının ise 2.16 (katılmıyorum) düzeyinde olduğu görülmektedir. Bu sonuca göre öğretmenlerin yarıdan fazlasının programın tanıtılması ve uygulanmasıyla ilgili yeterli hizmet içi eğitimi almadıklarını düşündükleri söylenebilir.

- "Program hakkında istediğim bilgiye anında ulaşabiliyorum" önermesine öğretmenlerin o12'sinin tamamen katıldıkları, 56'sının katıldıkları, 14 'ünün kararsız, 6'sının ise "hiç katılmadıkları" yönünde görüş bildirdikleri görülmektedir. Genel ortalama puanlarının 3.54(katılıyorum) düzeyinde olması bu durumu doğrulamaktadır.

- "Program içeriğinin açıklayıcı ve anlaşılır olduğunu düşünüyorum" önermesine öğretmenlerino10'unun "tamamen katılıyorum" \%42'sinin "katılıyorum", 32'sinin "kararsızım", 14'ünün"katılmıyorum", 2 sinin ise "hiç katılmadıkları" düzeyinde görüş bildirdikleri, genel ortalama puanlarının ise 3.44 (katılıyorum) düzeyinde olduğu görülmektedir. Bu sonuca göre öğretmenlerin program içeriğinin açıklayıcı ve anlaşılır olduğunu düşündükleri söylenebilir.

- Öğretmenlerin "Programın ders yılı başında tekrar tanıtılması gerektiğini düşünüyorum" önermesine ilişkin görüşleri incelendiğinde; 34'ünün "tamamen katılıyorum", 48'inin "katılıyorum", 12'sinin "kararsızı" ve ㅇ'sının "katılmıyorum" düzeyinde görüş bildirdikleri görülmektedir. Genel ortalama puanlarının 4.10 (katılıyorum) düzeyinde olması bu durumu doğrulamaktadır.

- "Geçmiş programdan yeni programa geçişte sorun yaşamadım" önermesine öğretmenlerin o6'sının "tamamen katılıyorum" ve "katılıyorum" düzeyinde, 66'sının "katılmıyorum", 6'sının ise "hiç katılmıyorum" düzeyinde görüş bildirdikleri, genel ortalama puanlarının ise 2.40 (katılmıyorum) düzeyinde olduğu görülmektedir. Bu sonuca göre öğretmenlerin çoğunluğunun geçmiş programdan yeni programa geçişte sorun yaşadıkları söylenebilir.

- "Ders kitabı kullanılmamasının öğrencinin derse karşı ilgisini artırabileceğini düşünüyorum" önermesine öğretmenlerin \%6'sının "tamamen katılıyorum", 32'sinin "katılıyorum", 26'sının "kararsızım", 18'inin "katılmıyorum", 18'inin "hiç katılmıyorum" düzeyinde görüş bildirdikleri, genel ortalama puanlarının ise 2.90 (kararsızım) düzeyinde olduğu görülmektedir.

- Öğretmenlerin "Programı uygulamada sorunlar yaşıyorum" önermesine ilişkin görüşleri incelendiğinde; o18'inin "tamamen katılıyorum" 64'ünün "katılıyorum", ㄷㅇ'unun "kararsızım" ve o8'inin "katılmıyorum" düzeyinde görüş bildirdikleri görülmektedir. Genel ortalama puanlarının 3.92 (katılıyorum) düzeyinde olması bu durumu doğrulamaktadır. Bu sonuca göre öğretmenlerin programı uygulamada sorunlar yaşadıkları söylenebilir.

- Öğretmenlerin "Ünitelerde seviyesinin üstündedir"

yer alan bazı kazanımlar öğrenci önermesine ilişkin görüşleri 
incelendiğinde; 34'ünün "tamamen katılıyorum" 56'sının "katılıyorum", 2'sinin "kararsızı" ve ㅇ'inin "katılmıyorum" düzeyinde görüş bildirdikleri, genel ortalama puanlarının ise 4.16 (katılıyorum) düzeyinde olduğu görülmektedir. Bu sonuca göre öğretmenlerin yarıdan fazlasının ünitelerde yer alan bazı kazanımların öğrenci seviyesinin üstünde olduğunu düşündükleri söylenebilir.

- "Ünitelerin işlenişinde yapılması gereken etkinliklerin yeterli olduğunu düşünmüyorum" önermesine öğretmenlerin o8'inin "tamamen katılıyorum", 20'sinin "katılıyorum", 20'sinin "kararsızım", \%48'inin "katılmıyorum" düzeyinde görüş bildirdikleri, genel ortalama puanlarının ise 2.80 (kararsızım) düzeyinde olduğu görülmektedir.

- "Programın öğrencilerin yaşantısını dikkate alarak çevreyle etkileşimine olanak sağladığını düşünüyorum" önermesine öğretmenlerin 일 "tamamen katılıyorum", 42'sinin "katılıyorum", 32'sinin "kararsızım", 14'ünün "katılmıyorum", o10'unun "hiç katılmıyorum" düzeyinde görüş bildirdikleri, genel ortalama puanlarının ise 3.12 (kararsızım)düzeyinde olduğu görülmektedir.

Programın ölçme ve değerlendirme boyutuna ilişkin maddeler incelendiğinde;

- "Yeni ölçme değerlendirme tekniklerini geleneksel değerlendirme anlayışına göre daha iyi buluyorum" önermesine öğretmenlerin \%4' ünün "tamamen katılıyorum", 50'sinin "katılıyorum", 30'unun "kararsızım", 高'sinin "katılmıyorum", 高' ünün "hiç katılmıyorum" düzeyinde görüş bildirdikleri, genel ortalama puanlarının ise 3.38 (kararsızım) düzeyinde olduğu görülmektedir.

- Öğretmenlerin "Ölçme ve değerlendirme formlarını kullanırken zorlanmıyorum" önermesine ilişkin görüşleri incelendiğinde; \%14'ünün "katılıyorum" ㅇ'sının "kararsızım" ve \%54'ünün "katılmıyorum", 응 6'sının "hiç katılmıyorum" düzeyinde görüş bildirdikleri, genel ortalama puanlarının ise 2.48 (katılmıyorum) düzeyinde olduğu görülmektedir. Bu sonuca göre öğretmenlerin ölçme ve değerlendirme formlarını kullanırken zorlandıkları düşünülebilir.

- "Ölçme ve değerlendirme formlarının kullanımının yorucu olduğunu düşünüyorum" önermesine öğretmenlerin ㄷ'sının "tamamen katılıyorum", 64'ünün "katılıyorum", 叫'ünün "kararsızım", o6'sının ise "katılmıyorum" düzeyinde görüş bildirdikleri, genel ortalama puanlarının ise 3.90 (katılıyorum) düzeyinde olduğu görülmektedir. Bu sonuca göre öğretmenlerin ölçme ve değerlendirme formlarının kullanımının yorucu olduğunu düşündükleri söylenebilir.

Diğer maddeler incelendiğinde;

- "Program farklı zeka gruplarına cevap verebilecek niteliktedir" önermesine öğretmenlerin \%36'sının "katılıyorum", \%42'sinin "kararsızım", 14'ünün "katılmıyorum", 8'inin "hiç katılmıyorum" düzeyinde görüş bildirdikleri, genel ortalama puanlarının ise 3.06 (kararsızım) düzeyinde olduğu görülmektedir.

- Öğretmenlerin "Konuların işlenebilmesi için ders saatini yeterli bulmuyorum" önermesine ilişkin görüşleri incelendiğinde; ㅇ' sının "tamamen katılıyorum", ㅇ''sinin ise "katılıyorum" düzeyinde görüş bildirdikleri, genel ortalama puanlarının ise 4.90 (tamamen katılıyorum)düzeyinde olduğu görülmektedir. Bu sonuca 
göre öğretmenlerin konuların işlenebilmesi için ders saatini yeterli bulmadıkları söylenebilir.

- "Programın öğrenci merkezli olması işimi kolaylaştırıyor" önermesine öğretmenlerin 14'ünün "tamamen katılıyorum", \%42'sinin "katılıyorum", 年32'sinin "kararsızım", 年'inin "katılmıyorum", $\frac{\circ}{4}$ 'ünün "hiç katılmıyorum" düzeyinde görüş bildirdikleri, genel ortalama puanlarının ise 3.54 (katılıyorum) düzeyinde olduğu görülmektedir. Bu sonuca göre öğretmenlerin programın öğrenci merkezli olmasının işlerini kolaylaştırdığını düşündükleri söylenebilir.

- Öğretmenlerin "Yeni programın öğrencinin kendine güvenini ve yaratıcılığını artırabileceğini düşünüyorum" önermesine ilişkin görüşleri incelendiğinde; \%16'sının "tamamen katılıyorum" \%44'ünün "katılıyorum", 22'sinin "kararsızı" ve \%12'sinin ise "katılmıyorum", 6 sının ise "hiç katılmıyorum" düzeyinde görüş bildirdikleri, genel ortalama puanlarının ise 3.52 (katılıyorum) düzeyinde olduğu görülmektedir.

- "Yeni programın eğitim sistemine yeni bir soluk getireceğini düşünüyorum" önermesine öğretmenlerin 6'sının "tamamen katılıyorum", 38'inin "katılıyorum", \%42'sinin "kararsızım", 6'sının "katılmıyorum", ㅇ'inin ise "hiç katılmıyorum" düzeyinde görüş bildirdikleri, genel ortalama puanlarının ise 3.28 (kararsızım) düzeyinde olduğu görülmektedir.

Ankette yer alan açık uçlu sorulara verdikleri cevaplar doğrultusunda yapılan içerik analizleri sonucu, öğretmenlerin ortaöğretim müzik dersi öğretim programının olumlu ve olumsuz buldukları yönleri frekans yoğunlukları dikkate alınarak Tablo 4'de gösterilmiştir.

Tablo 4. Müzik öğretmenlerinin ortaöğretim müzik dersi öğretim programının olumlu ve olumsuz buldukları yönleri

(Table 4. The positive and negative views of music teachers about secondary school music lessons curriculum)

\begin{tabular}{|c|c|c|}
\hline & $\mathrm{f}$ & \\
\hline \multirow{4}{*}{$\begin{array}{l}\text { Olumlu } \\
\text { Buldukları } \\
\text { Yönleri }\end{array}$} & 11 & Öğretmenin ders işleyiş yükü azalması \\
\hline & 9 & Programın detaylı hazırlanması \\
\hline & 9 & Öğrenci merkezli olması \\
\hline & 2 & Ölçme-değerlendirmenin kolaylaşması \\
\hline \multirow{4}{*}{$\begin{array}{l}\text { Olumsuz } \\
\text { Buldukları } \\
\text { Yönleri }\end{array}$} & 23 & Ders saatine göre düşünüldüğünde fazla ayrıntılı olması \\
\hline & 9 & Kılavuz kitabın bulunmaması \\
\hline & 9 & Kazanımların öğrenci seviyesinin üzerinde olması \\
\hline & 7 & Ölçme-değerlendirme formlarının uygulamaya yansıyamaması \\
\hline
\end{tabular}

Müzik öğretmenlerinin programın uygulanmasıyla ilgili görüş, öneri ve beklentilerine doğrudan alıntılarla aşağıda yer verilmiştir:

"Müzik dersinin ve programın verimli bir şekilde işlenebilmesi için 9-10-11 ve 12.sınıflarda her yıl olması (zorunlu olarak)gerekir, öğrencinin 9. Sınıfta dersi alıp, 10 ve 11. sınıfta görmeyip 12.sınıfta tekrar görmesi konuları işlemede sıkıntı yaratıyor. 9. Sınıfta seçmeli olan dersin mezun olana kadar sürmesi gerekir."

"Ders saatlerinin ve öğrencinin alt yapısının yetersiz oluşu programın uygulamasını zorlaştırıyor"

"Müzik programının gerçek anlamda uygulanabilmesi ve amacına ulaşabilmesi için gerekli donanımlı müzik sınıfları ve ders saatinin haftada en az 2 saat olması gerekir".

"Öğretmene mutlaka bir kılavuz kitap gönderilmeli".

"Programın içeriği doktora tezi olabilecek nitelik ve kalitede olabilir, ancak uygulama anlamında mevcut ders saati, öğrenci profile 
ve okullardaki idareci profillerinin müzik dersini seçerken belirlediği ölçütler uygulamayı neredeyse imkansız kılıyor".

"Program çok kapsamlı fakat bu kapsamı aşılamak için gerekli ortamların sağlanması ve gerekli malzemelerin bulunması öğrencilerin etkinliklerine yardımcı olacaktır. Müzik derslerine branş öğretmenlerinin girmesi ve gereken ders saatinin uygulanması anlamında çalışmalar yapılması lazım".

\section{SONUÇ VE ÖNERILLER (CONCLUSION AND RECOMMENDATIONS)}

2010-2011 eğitim öğretim yılından itibaren uygulanmakta ve yapılandırmacı yaklaşıma dayalı olan ortaöğretim müzik dersi öğretim programını Mersin ilinde görev yapmakta olan müzik öğretmenlerinin bakış açısıyla değerlendirmeyi amaçlayan araştırmada elde edilen bulgular sonucu öğretmenlerin "tamamen katılıyorum" ve "katılıyorum" düzeyinde görüşbildirdikleri en yüksek frekansa ve ortalamaya sahip maddelerin "konuların işlenebilmesi için ders saatini yeterli bulmuyorum" $(\mathrm{f}=48, \bar{X}=4.90)$, "Ünitelerde yer alan bazı kazanımlar öğrenci seviyesinin üstündedir" (f=45, $\bar{X}=4.16)$, "Programın ders yılı başında tekrar tanıtılması gerektiğini düşünüyorum" $(f=41, \bar{X}=4.10)$, "Programı uygulamada sorunlar yaşıyorum" (f=41, $\bar{X}=3.92)$, "Ölçme ve değerlendirme formlarının kullanımının yorucu olduğunu düşünüyorum" (f=40, $\bar{X}=3.90)$, "Programın hazırlanma aşamasında yeterli ön hazırlığın yapıldığını düşünmüyorum" (f=32, $\bar{X}=3.54)$, "Program hakkında istediğim bilgiye anında ulaşabiliyorum", (f=34, $\bar{X}=3.54)$ "Programın öğrenci merkezli olması işimi kolaylaştırıyor" (f=28, $\bar{X}=3.54)$, "Yeni programın öğrencinin kendine güvenini ve yaratıcılığını artırabileceğini düşünüyorum" (f=30, $\bar{X}=3.52)$, "Program içeriğinin açıklayıcı ve anlaşılır olduğunu düşünüyorum" (f=26, $\bar{X}=3.52)$ olduğu görülmektedir. Öğretmenlerin açık uçlu sorulara verdikleri cevaplar doğrultusunda yapılan içerik analizleri sonucu, öğretmenler tarafından ortaöğretim müzik dersi öğretim programının olumlu buldukları yönleri; "Öğretmenin ders işleyiş yükünü azaltması" (f=11), "Programın detaylı hazırlanması" ( $f=9)$, "Öğrenci merkezli olması" (f=9), "Ölçmedeğerlendirmenin kolaylaşması" (f=2), olumsuz buldukları yönleri ise "Ders saatine göre düşünüldüğünde fazla ayrıntılı olması" (f=23), "Kılavuz kitabın bulunmaması" ( $\mathrm{f}=9$ ), "Kazanımların öğrenci seviyesinin üzerinde olması" (f=9), "Ölçme-değerlendirme formlarının uygulamaya yansıyamaması" ( $f=7)$ olarak belirlenmiştir.

Araştırmaya katılan öğretmenlerin programın uygulama boyutuyla ilgili yansıttıkları görüşleri ağırlıklı olarak; müzik dersinin haftada bir saat ve seçmeli ders olmasının, her sene farklı derslerin seçilebilmesinin ve devamlılığının bulunmamasınınprogramın uygulanması aşamasında sorunlar yarattığı ve öğretim programının sağlıklı olarak uygulanmasını güçleştirdiği, okullardakimüzikseldonanımların (müzik dersliği, ders araç ve gereçleri, teknolojik donanımlar) yetersiz oluşunun dersin gereklerini yerine getirirken güçlükler yarattığı, öğrencilerin alt yapılarındaki eksiklikler ve kazanımların öğrenci seviyesinin çok üzerinde olmasınınuygulamada sıkıntılar yaşattığıve öğretmenlerin faydalanmaları için kılavuz kitap hazırlanması gerektiği yönündedir.

Araştırma sonucu elde edilen bulgular ışığında sunulan öneriler aşağıda yer almaktadır: 
- "Türkiye'de yeni programın uygulanması sürecinde karşılaşılan sorunlara bakıldığında, programın öğrenci ve öğretmen için getirdiği yeni rollerin öğretmenler tarafından yeterince anlaşılmadığı gözlenmiştir (Bıkmaz, 2006). Bunun en önemli sebebi, öğretmenlerin yeterince hizmetiçi eğitim almamaları olarak görülebilir" (Bal, 2008, Akt. Keleş, Haser ve Koç, 2012:717). Yapılacak hizmetiçi eğitimler yoluyla öğretmenlerin bilgi paylaşımında bulunmalarının öğretim programının daha etkin uygulanmasını sağlayabileceği düşünülmektedir.

- Mevcut müzik derslerinin seçmeli ders statüsünden çıkartılarak ders saatleri süreleri artırılması yoluyla eğitimde bütünlüğü ve öğretim programının sağlıklı bir şekilde uygulanmasını sağlayacağı düşünülmektedir.

- Okulların müziksel donanımlarının arttırılmasının öğretmen ve öğrenci motivasyonunu artırarak yapılandırmacı öğretim programının uygulanmasını kolaylaştıracağı düşünülmektedir.

- Programın uygulayıcısı olan müzik öğretmenlerinin "öğretim programındaki kazanımların öğrenci seviyesinin üstünde" olması görüşleri ışığında programın revize edilerek sadeleştirilmesi önerilmektedir.

- Seven'e göre (2002) kılavuz kitaplar, öğrenmenin yaptıracağı etkinlikleri, bunların sırasını, nasıl yapılacağını göstererek daha kısa zamanda öğrenciye rehberlik edilmesini kolaylaştırır ve sınıf içinde disiplin problemlerinin de en aza indirilmesinde önemli bir etkiye sahiptir (Kılıç, 2009:297; Akt. Bulut, 2012:112). Bu doğrultuda öğretmenlere rehberlik edecek kılavuz kitapların hazırlanması.

- Benzer araştırmaların daha geniş bir örneklemle farklı illerde görevli müzik öğretmenlerinin görüşleri doğrultusunda yapılması önerilmektedir.

\section{KAYNAKÇA (REFERENCES)}

1. Bıkmaz, F.H., (2006). Yeni ilköğretim programları ve öğretmenler. Ankara Üniversitesi Eğitim Bilimleri Fakültesi Dergisi, $39(1)$, ss:97-116 http://dergiler.ankara.edu.tr/detail.php?id=40\&sayi id=148

2. Bulut, D., (2012). İlköğretim 8. sınıf müzik dersi öğretmen kılavuz kitabına ilişkin eleştirel bir bakış. International Journal of Human Sciences [Online], (9)2, ss: 109- 125.

3. Dinç, E. ve Doğa, Y., (2010). İlköğretim ikinci kademe sosyal bilgiler öğretim programı ve uygulanması hakkında öğretmen görüşleri, Journal of Social Studies Education Research, 1 (1), ss:17-49, wWw.sosyalbilgiler.org

4. Keleş, Ö., Haser, Ç. ve Koç, Y., (2012). Sınıf öğretmenlerinin ve ilköğretim matematik öğretmenlerinin yeni ilköğretim matematik dersi programı hakkındaki görüşleri, Gaziantep Üniversitesi Sosyal Bilimler Dergisi, $11(3)$, ss:715-736, (http://sbe.gantep.edu.tr)

5. Korkmaz, İ., (2006). Yeni ilköğretim birinci sınıf programının öğretmenler tarafından değerlendirilmesi. Selçuk Üniversitesi, Sosyal Bilimler Enstitüsü Dergisi, 16, ss:419-431.

6. M.E.B., (2009). Ortaöğretim müzik dersi (9, 10, 11 ve 12 . sınıflar) öğretim programı, Ankara: Talim Terbiye Kurulu Başkanlığı.

7. Özden, Ö., (2010).Ortaöğretimde müzik eğitimi haftalık ders saatlerine ilişkin talim terbiye kurulu kararının müzik öğretmenleri üzerindeki etkileri, NWSA: Fine Arts, Volume: 5, Number: 4, pp:295-311. 